Vidya Wertta Volume 3 Nomor 1 Tahun 2020

p-ISSN 0852-7776-e-ISSN 2655-7282

https://ejournal.unhi.ac.id/index.php/vidyawertta

\title{
TRADISI PERANG PISANG DI DESA TENGANAN DAUH TUKAD KABUPATEN KARANGASEM
}

\author{
I Wayan Dauh \\ Desak Nyoman Seniwati \\ wayandauh@unhi.ac.id
}

Fakultas Ilmu Agama, Seni dan Budaya

Universitas Hindu Indonesia

\begin{abstract}
ABSTRAK
Tradisi Perang Pisang dilaksanakan masyarakat Desa Tenganan Dauh Tukad didasari oleh beberapa landasan, yaitu : 1) landasan histori, berkaitan dengan usaha Jro mangku Dukuh untuk melestarikan tradisi Perang Pisang; 2) landasan teologi, yaitu sebagai ungkapan rasa angayubagia (terimakasih dan syukur) kehadapan Ida Sanghyang Widhi/Tuhan Yang Maha Esa atas anugrah kemakmuran yang dinikmati masyarakat; 3) landasan filosofi, berhubungan dengan kepercayaan bahwa tradisi Perang Pisang itu sesungguhnya adalah sebagai bentuk persembahan yadnya juga; dan 4) landasan sosiologi berhubungan erat dengan struktur kepemimpinan sosial masyarakat desa Tenganan Dauh Tukad terutama dalam hal memilih calon pemimpin (ayah dan penampih) dari seke terunanya agar memperoleh pemimpin yang sesuai dengan nilai-nilai etika Hindu. Prosesi tradisi Perang Pisang ini dimulai dari tahap persiapan, pelaksanaan dan penutup yang kesemua itu dijalankan dengan penuh kepatuhan oleh masyarakat setempat. Sedangkan nilai-nilai etika yang terdapat pada tradisi Perang Pisang.
\end{abstract}

Kata kunci: tradisi, perang pisang

\begin{abstract}
The tradition of the Banana War is carried out by the people of Tenganan Dauh Tukad Village based on several reason, namely: 1) the historical foundation, related to the efforts of Jro mangku Hamlet to preserve the Banana War tradition; 2) theological foundation, namely as an expression of angayubagia (thank you and gratitude) to Ida Sanghyang Widhi / God Almighty for the gift of prosperity enjoyed by the community; 3) philosophical foundation, related to the belief that the Banana War tradition is actually a form of offering also; and 4) the foundation of sociology is closely related to the social leadership structure of the Tenganan Dauh Tukad village community, especially in terms of choosing prospective leaders (fathers and leaders) from their schools to obtain leaders who are in
\end{abstract}

\section{3}


accordance with Hindu ethical values. The procession of the Banana War tradition starts from the preparation, implementation and closing stages which are all carried out in full compliance by the local community. While the ethical values contained in the Banana War tradition.

Keywords: tradition, banana war

\section{PENDAHULUAN}

Alam semesta beserta isinya merupakan ciptaan Tuhan Yang Maha Esa/ Ida Sang Hyang Widhi. Ciptaan Tuhan yang paling sempurna adalah manusia. Manusia dalam kehidupannya telah dibekali pramana yang paling lengkap daripada makhluk yang lain sesama ciptaan Tuhan. Oleh karena itu, manusia sebagai subyek, makhluk yang utama mempunyai tugas dan kewajiban untuk memelihara dunia dengan segala isinya, guna dirawat dan dilestarikan serta diwariskan kepada anak cucu untuk kepentingan hidup manusia baik lahir maupun bathin.

Tradisi merupakan salah satu bentuk dari pelaksanaan yadnya, yaitu suatu penghormatan kepada para leluhur. Tradisi yang dilaksanakan dalam masyarakat Hindu di Bali cenderung merupakan kebiasaan atau warisan leluhur terdahulu. Sehingga, sudah menjadi kewajiban untuk selalu melaksanakan dan melestarikan tradisi yang ada dalam suatu masyarakat agar tidak mengalami kepunahan. Namun tradisi yang ada di Desa Tenganan ini tentu sudah mulai perubahan dalam bentuk, struktur dalam proses mencari peminpin yang kuat fisik maupun mental, dalam proses pembentukan calon peminpin tentu sudah mulai pergeseran makna, etika dalam bentuk proses terjadinya mencari peminpin di Desa Tenganan.

Bagi manusia yang religius, keberadaan ritual memang penting dalam kehidupannya. Melalui upacara, manusia religius membangun semangat baru dalam kehidupannya yang juga menggantungkan sebagai angan dan cita-citanya menuju kehidupan yang lebih baik. Dalam mewujudkan angan dan cita-cita kehidupannya, banyak jalan yang ditempuh manusia seperti jalan rasional dan jalan mistis. Pendekatan rasional tidak saja selamanya mampu membawa manusia yang seiring jalan sesuai dengan apa yang diharapkan. Dengan demikian, maka manusia juga memerlukan jalan mistis untuk mewujudkan harapannya. Maksud dari jalan mistis ini adalah melalui upacara ritual keagamaan. Ritual diharapkan menjadi kekuatan yang mampu menghubungkan manusia dengan yang gaib. Kehadiran spirit yang gaib (Tuhan atau Dewa) diharapkan menjadi kekuatan yang menuntun dan mengarahkan manusia ke jalan yang benar menuju pencapaian hidupnya sesuai dengan apa yang diharapkan. Untuk mewujudkan keinginannya itu, umat Hindu pada praktik kesehariannya melaksanakan upacara yadnya.

Secara niskala, perang pisang merupakan penyampaian rasa syukur atau terima kasih masyarakat kepada Ida Sang Hyang Widhi atas hasil panen yang telah diperoleh. Selain itu, secara sekala perang pisang merupakan ajang untuk memilih calon pemimpin, yaitu calon ketua dan wakil ketua pemuda. Berbeda dengan di daerah-daerah lain yang pemilihan calon pemimpin dilakukan dengan

\section{4}

\section{VIDYA WERTTA}

Vol. 3 Nomor 1, April 2020 
cara musyawarah atau pemilihan langsung, namun di Desa Tenganan Dauh Tukad, pemilihan calon pemimpin itu dilaksanakan melalui pelaksanaan tradisi Perang Pisang, yang mana dimaksudkan untuk menguji fisik sekaligus mental para calon pemimpin.

Perang Pisang merupakan tradisi bagi pemuda Desa (truna adat) dalam rangka pemilihan dan menguji fisik maupun mental calon pemimpin di Desa Tenganan Dauh Tukad. Pemuda Desa (Truna adat) merupakan suatu organisasi yang beranggotakan hanya pemuda yang berusia diatas 13 tahun. Jadi, tidak ada keterlibatan gadis Desa (deha adat) dalam pelaksanaan perang pisang, karena tradisi perang pisang adalah tradisi khusus bagi pemuda Desa (truna adat) di Desa Tenganan Dauh Tukad. Dalam pelaksanaan perang pisang biasanya dipilih dua orang pemuda (Teruna Adat) yang dipersiapkan untuk menjadi ketua (Saye) dan wakil ketua (Penampih) teruna adat. Kedua pemuda yang dipilih sebagai Saye dan Penampih tersebut nantinya akan menjadi lawan atau sasaran utama serangan perang pisang (siat biu) yang dilakukan oleh belasan pemuda lainnya pada saat aci/upacara perang pisang.

Serangan tersebut merupakan bagian dari aturan yang harus dijalankan untuk menguji fisik maupun mental calon pemimpin di Desa Tenganan Dauh Tukad. Tidak jarang wajah kedua pemuda yang menjadi sasaran itu mengalami memar dan bahkan sampai terluka. Kesemua itu adalah semacam bentuk uji ketangguhan fisik, uji kekuatan nyali termasuk uji kesiapan mental sebelum nantinya benar-benar terpilih sebagai pemimpin truna adat, yang bisa dibanggakan sekaligus diharapkan dapat memimpin kelompok pemuda desa. Jadi untuk menjadi pemimpin di tingkat bawah dalam hal truna adat, mereka sudah mulai digembleng dengan berbagai cara, termasuk melalui pergelaran tradisi Perang Pisang yang sampai saat ini masih dilestarikan.

\section{METODE PENELITIAN}

Rancangan penelitian dibutuhkan untuk memperjelas dan mempermudah pencarian data dan penyelesaian penelitian ini. Menurut Moleong (dalam Satori dan Komariah, 2011:83) menyebutkan bahwa, rancangan penelitian dapat diartikan sebagai usaha merencanakan dan menentukan segala kemungkinan serta perlengkapan yang diperlukan dalam suatu penelitian kualitatif.

Penelitian ini merupakan penelitian kualitatif yang bertujuan untuk mengetahui sejarah, pelaksanaan dan nilai-nilai pendidikan yang terkandung dalam tradisi Perang Pisang. Pendekatan yang digunakan dalam upaya lebih memahami tentang tradisi Perang Pisang di Desa Tenganan Dauh Tukad adalah melalui pendekatan kualitatif. Karena pendekatan kualitatif bersifat mengungkap, memahami, dan menjelaskan suatu fenomena atau masalah yang sedang diteliti untuk mendapatkan informasi yang terkait dengan penelitian yang dilaksanakan.

Dengan pernyataan di atas jelas bahwa pendekatan kualitatif berguna untuk mengetahui segala sesuatu yang belum diketahui, sehingga dapat diketahui hal-hal apa saja yang terkandung di dalamnya. Untuk memahami hal tersebut, data-data yang diperoleh dikumpulkan dengan menggunakan beragam cara yaitu dengan melakukan

\section{5}

\section{VIDYA WERTTA}

Vol. 3 Nomor 1, April 2020 
pengamatan (observasi), wawancara (interview) dan pengumpulan dokumen atau pustaka yang berkaitan dengan masalah yang diteliti.

\section{PEMBAHASAN}

\subsection{Landasan Pelaksanaan Tradisi Perang Pisang di Desa Tenganan Dauh Tukad, Kabupaten Karangasem}

Manusia adalah makhluk berperilaku, dapat bertindak atau berbuat melakukan sesuatu. Bekerja, berjalan, makan, minum, mandi, tidur, melamun, bermain, belajar, olah raga, berdoa, sembahyang, dan masih banyak lagi aktivitas yang bisa dan biasa dilakukan oleh makhluk bernama "manusia". Manusia berperilaku digerakkan atau didorong oleh sesuatu, sesuai kebutuhan, keperluan, atau keinginannya. Manusia berperilaku sesuai hakikatnya sebagai "human being" (makhluk yang ada), sehingga selalu bereksistensi untuk menunjukkan keberadaanya.

Berbicara tentang manusia, terutama yang berkaitan dengan perbuatan atau perilakunya, menurut Poerwadarminta (1986: 738) dalam Kamus Besar Bahasa Indonesia dinyatakan, bahwa : "Perilaku" adalah cara berbuat atau menjalankan sesuatu dengan sifat yang layak bagi masyarakat". Sedangkan Alport (dalam Rahmat, 2001: 201) menyatakan, perilaku merupakan hasil belajar yang diperoleh melalui pengalaman dan interaksi yang terus menerus dengan lingkungan. Seringnya dalam lingkup lingkungan, akan menjadikan seseorang dapat menentukan sikap karena disadari atau tidak, perilaku tersebut tercipta akibat pengalaman yang di alaminya.

Sedangkan menurut Sarwono (1996: 24), tingkah laku merupakan perbuatan manusia yang tidak terjadi secara sporadis (timbul dan hilang disaat-saat tertentu), tetapi ada kelangsungan (kontinuitas) antara satu perbuatan dengan perbuatan lainnya.

Tak terkecuali dengan apa yang dilakukan masyarakat di Desa Tenganan Dauh Tukad, Kabupaten Karangasem yang secara turun-temurun melaksanakan tradisi Perang Pisang. Tradisi Perang Pisang ini merupakan bentuk kebiasaan berperilaku yang memiliki beberapa landasan yang melatarbelakanginya, yaitu :

\section{Landasan Histori}

Secara historis, pelaksanaan tradisi Perang Pisang memang tidak ditemukan sumber tertulis, semisal dalam bentuk naskah kepustakaan, seperti model lontar yang secara spesifik membahasnya. Apa yang selama ini dijalankan masyarakat Desa Tenganan Dauh Tukad dalam bentuk tradisi Perang Pisang lebih banyak diketahui melalui cerita rakyat (lisan) yang secara turun temurun sedemikian rupa diwarisi dan bersandar pada adagium gugon tuwon anak mulo keto, memang sudah demikian rupa adanya.

Menurut keterangan yang disampaikan I Nyoman Puri (49 tahun selaku Bendesa Desa Tenganan Dauh Tukad dikatakan bahwa : 
"Sejarah berlangsungnya tradisi Perang Pisang itu sendiri berkaitan erat dengan sejarah Desa Tenganan Dauh Tukad, yang merupakan sebuah desa dimana tradisi Perang Pisang dilaksanakan. Pada zaman dahulu ketika masa Pra Majapahit, yaitu pada masa pemerintahan Raja Dukuh Mangku di Tenganan Dauh Tukad, Beliau dikenal sebagai raja yang sangat sakti, Beliau mewariskan berbagai tradisi kepada masyarakatnya, salah satunya adalah tradisi perang pisang. Melalui tradisi tersebut Beliau selalu mengajarkan disiplin kepada para prajuritnya, selain itu melalui Perang Pisang juga diharapkan akan tercipta prajurit-prajurit yang tangguh. Setelah kedatangan Raja Dalem Gelgel ke Bali dengan para prajuritnya, yang ingin menguasai semua kerajaan agar menjadi daerah kekuasaanya dan menghapuskan semua tradisi yang ada di Bali, termasuk tradisi yang ada di Desa Tenganan Dauh Tukad. Namun Raja Dukuh Mengku tidak bisa menerima kedatangan Raja Dalem Gelgel yang ingin berkuasa di kerajaannya dan menghapuskan semua tradisi yang ada. Sehingga terjadilah perang antara kerajaan Dukuh Mengku dengan Raja Dalem Gelgel beserta dengan semua prajuritnya. Peperangan tersebut membuat kerajaan Raja Dukuh Mengku mengalami kekalahan, karena jumlah prajurit Raja Dalem Gelgel melebihi prajurit Raja Dukuh Mengku. Dalam kekalahannya tersebut beliau berpesan dan akan menyerahkan semua wilayah kekuasaan serta kerajaannya kepada Raja Dalem Gelgel dengan syarat agar semua tradisi dan Aci (upacara) yang ada di Desa Tenganan Dauh Tukad tetap dilaksanakan sebagaimana mestinya (Wawancara, tanggal 6 Agustus 2019).

Berpijak pada hasil wawancara di atas, dapat dikatakan bahwa pada umumnya sifat-sifat baik yang dimiliki oleh seseorang akan dapat menentukan keberhasilan kepemimpinannya. Setiap pribadi pemimpin harus memiliki tenaga jasmani dan rohani yang baik, yaitu mempunyai daya tahan, keuletan yang tidak akan pernah habis. Apabila ditambah dengan kekuatan-kekuatan mental berupa semangat juang, motivasi kerja, disiplin dan kesabaran yang tinggi serta kemampuan inteletual akan mampu untuk mengatasi semua permasalahan yang dihadapi. namun masyarakat Desa Tenganan Dauh Tukad memilih calon pemimpin melalui pelaksanaan perang pisang, yang mana dimaksudkan sebagai ujian untuk melatih fisik maupun mental calon-calon pemimpin agar didapatkan pemimpin yang tangguh, sehingga dapat menjalankan kepemimpinannya dengan baik.

Hal tersebut seperti senada dengan pendapat Mertha Sutedja (dalam Erawati, 2013: 47), bahwa secara garis besar ada enam sifat yang harus dimiliki oleh seorang pemimpin, salah satunya adalah kapasitas intelektuil. Kapasitas intelektuil yaitu seorang pemimpin harus mempunyai kemampuan intelektuil yang menonjol yang dapat mempengaruhi orang banyak yang intelektualitasnya biasa, kapasitas intelektual ini meliputi sifat-sifat iman seperti : mental, moral, kepekaan

\section{7}

\section{VIDYA WERTTA}

Vol. 3 Nomor 1, April 2020 
sosial, kecakapan dalam berbagai lapangan, dan kemampuan dalam memecahkan berbagai masalah.

\section{Landasan Teologi}

Secara teologis, pelaksanaan tradisi perang pisang adalah sebagai wujud persembahan kehadapan Ida Sang Hyang Widhi beserta manifestasinya yang telah menganugrahkan umatnya berbagai macam keperluan kehidupan. Sebagai ungkapan rasa terimakasih dan syukur, dengan menggunakan berbagai macam dan jenis anugrah itu pula umat Hindu, dalam hal ini krama Desa Tenganan Dauh Tukad mewujudkannya dengan melaksanakan tradisi Perang Pisang. Oleh karena itu, tradisi Perang Pisang ini dapat juga diapandang sebagai bentuk persembahan yadnya, sebagaimana Tuhan (Prajapati) mencipta dunia dengan yadnya pula. Kongkritnya, persembahan dalam bentuk melakukan tradisi Perang Pisang merupakan wujud bhakti kehadapan Tuhan Yang Maha Esa, yang telah memberikan kesejahteraan, kesuburan atau kemakmuran, dimana segala apa yang dibudidayakan dalam lahan pertanian atau perkebunan dapat berhasil dengan baik, yang kesemua itu diyakini diberkati oleh kemurahan Tuhan.

Sebagai manusia, apalagi selaku umat Hindu bahwa apa yang dilakukan dalam bentuk tradisi, dalam hal ini tradisi Perang Pisang, sesungguhnya sudah sesuai dengan tuntunan kitab suci, khususnya suratan kitab Manawadharmasastra, II.6 yang menyatakan :

"Wedo'khilo dharma mulam smrti sile ca tad widam, acarasca iwa sadunam atmanasyutir ewa ca".

Artinya :

Seluruh weda merupakan sumber utama dari pada dharma (agama Hindu) kemudian barulah smrti di samping kebiasaan-kebiasaan yang baik dari orang-orang yang menghayati weda. Kemudian tradisi-tradisi dari orangorang suci serta akhirnya atmanastuti (rasa puas diri sendiri) (Pudja, dan Sudharta, 1977/1978: 57).

Jika diringkas, sumber kitab suci Manawadharmasastra di atas, memberikan petunjuk bahwa setiap pelaksanaan kewajiban sebagai umat Hindu, selalu mengacu pada sumber-sumber kebenaran (dharma), yaitu : 1) Sruti, 2) Smerti, 3) Sila, 4) Sadacara, dan 5) Atmanastuti. Penejelasannya :

1) Sruti sebagai Sumber Hukum Hindu Pertama

Di dalam Manawadharmasastra II.10 dikatakan

"Srutistu wedo wijneyo dharma sastram tu wai smerti, te sarwatha wam imamsye tabhyam dharmohi nirbhabhau”.

Artinya: 
Sesungguhnya Sruti adalah Weda, Smerti itu Dharmasastra, keduanya tidak boleh diragukan apapun juga karena keduanya adalah kitab suci yang menjadi sumber dari pada hokum (Pudja, dan Sudharta, 1977/1978: 59)..

Selanjutnya mengenai Weda sebagai sumber hukum utama, dapat dilihat dari sloka II. 6 dirumuskan sebagai berikut:

"Wedo khilo dharma mulam smerti sile ca tad widam, acarasca iwa sadhunam atmanas tustirewa ca".

Artinya :

Seluruh Weda sumber utama dari pada hukum, kemudian barulah smerti dan tingkah laku orang-orang baik, kebiasaan dan atmanastuti (Pudja, dan Sudharta, 1977/1978: 57).

Pengertian Weda sebagai sumber ilmu menyangkut bidang yang sangat luas sehingga Sruti dan Smerti diartikan sebagai Weda dalam tradisi Hindu. Sedangkan ilmu hukum Hindu itu sendiri telah membatasi arti Weda pada kitab Sruti saja. Kitab-kitab yang tergolong Sruti menurut tradisi Hindu adalah : Kitab Mantra, Brahmana dan Aranyaka. Kitab Mantra terdiri dari : Rg Weda, Sama Weda, Yajur Weda dan Atharwa Weda.

\section{2) Smrti sebagai Sumber Hukum Hindu Kedua}

Smrti merupakan kitab-kitab teknis yang merupakan kodifikasi berbagai masalah yang terdapat di dalam Sruti. Smrti bersifat pengkhususan yang memuat penjelasan yang bersifat authentik, penafsiran dan penjelasan ini menurut ajaran Hukum Hindu dihimpun dalam satu buku yang disebut Dharmasastra.

Dari semua jenis kitab Smrti yang terpenting adalah kitab Dharmasastra, karena kitab inilah yang merupakan kitab Hukum Hindu. Ada beberapa penulis kitab Dharmasastra antara lain: 1) Manu, 2) Apastambha, 3). Baudhayana, 4) Wasistha, 5) Sankha Likhita, 6) Yanjawalkya, 7) Parasara.

Dari ketujuh penulis tersebut, Manu yang terbanyak menulis buku dan dianggap sebagai standard dari penulisan Hukum Hindu itu. Secara tradisional Dharmasastra telah dikelompokkan manjadi empat kelompok menurut jamannya masing- masing yaitu:

(a) Jaman Satya Yuga, berlaku Dharmasastra yang ditulis oleh Manu.

(b) Jaman Treta Yuga, berlaku Dharmasastra yang ditulis oleh Yajnawalkya.

(c) Jaman Dwapara Yuga, berlaku Dharmasastra yang ditulis oleh Sankha

Likhita.

(d) Jaman Kali Yuga, berlaku Dharmasastra yang ditulis oleh Parasara.

3) Sila sebagai Sumber Hukum Hindu Ketiga

Sila di sini berarti tingkah laku. Bila diberi awalan su maka menjadi susila yang berarti tingkah laku orang-orang yang baik atau suci. Tingkah laku tersebut meliputi pikiran, perkataan dan perbuatan yang suci. Pada umumnya tingkah laku 
para maharsi atau nabi dijadikan standar penilaian yang patut ditauladani. Kaedahkaedah tingkah laku yang baik tersebut tidak tertulis di dalam Smerti, sehingga sila tidak dapat diartikan sebagai hukum dalam pengertian yang sebenarnya, walaupun nilai-nilainya dijadikan sebagai dasar dalam hukum positif.

\section{4) Sadacara sebagai Sumber Hukum Hindu Keempat}

Sadacara dianggap sebagai sumber hukum Hindu positif. Dalam bahasa Jawa Kuna Sadacara disebut Drsta yang berarti kebiasaan. Drsta inilah yang kemudian disebut sebagai tradisi. Untuk memahami pemikiran hukum Sadacara ini, maka hakekat dasar Sadacara adalah penerimaan Drsta sebagai hukum yang telah ada di tempat mana Hindu itu dikembangkan. Dengan demikian sifat hukum Hindu adalah fleksibel.

\section{5) Atmanastuti sebagai Sumber Hukum Hindu Kelima}

Atmanastuti artinya rasa puas pada diri sendiri. Perasaan ini dijadikan ukuran untuk suatu hukum, karena setiap keputusan atau tingkah laku seseorang mempunyai akibat. Atmanastuti dinilai sangat relatif dan subyektif, oleh karena itu berdasarkan Manawadharmasastra 109/115, bila memutuskan kaedahkaedah hukum yang masih diragukan kebenarannya, keputusan diserahkan kepada majelis yang terdiri dari para ahli dalam bidang kitab suci dan logika agar keputusan yang dilakukan dapat menjamin rasa keadilan dan kepuasan yang menerimanya (http://sumantre.blogspot.com/2010/10/hukum-hindu-sumbersumber-hukum-hindu.html).

Selain itu, sebagaimana dinyatakan oleh Panyarikan Desa Adatnya bernama I Wayan Togiya (45 tahun) :

"Memang benar secara teologi, adanya keyakinan bahwa kami masyarakat

Desa adat Tenganan Dauh Tukad ini merasakan sekali kemurahan rejeki yang kami dapatkan dan nikmati, berupa hasil bumi yang di dapat dari persawahan atau perkebnunan kami yang seakan tiada hentinya memberikan kesuburan hingga masyarakat kami hidup sejahtera tak kuran apapun" (Wawancara tanggal 10 Agustus 2019).

Berdasarkan paparan landasan teologi di atas, apa yang dilaksanakan masyarakat desa tenganan dauh Tukad dalam bentuk tradisi tersebut rupanya tergolong ke dalam "Sadacara" sebagai salah satu sumber kebenaran. Bahwa tradisi yang dilakukan masyarakat desa Tenganan Dauh Tukad ini meskipun secara literasi tidak begitu dikenal namun secara implisit sudah memiliki sumber kebenarannya, bahkan merujuk pada kebenaran Weda. Dimana tradisi Perang Pisang tersebut merupakan wujud bhakti dalam bentuk rasa terimakasih dan syukur (angayubagia dan astungkara) atas kelimpahan anugrah dari Ida Sanghyang Widhi Wasa/Tuhan Yang Maha Esa kepada masyarakat Tenganan Dauh Tukad.

\section{Landasan Filosofi}

Tradisi Perang Pisang ini menggunakan sarana penting berupa buah pisang. Menurut Ayu Ariani, buah pisang di Bali berperan penting dalam setiap 
upacara keagamaan. Dalam setiap banten atau upakara yang dibuat, pasti ada unsur pisang di dalamnya. Pisang termasuk buah yang mudah ditemukan. Pohon pisang bisa tumbuh subur tanpa perawatan khusus, sehingga tidak merepotkan. Jenisnya pun beragam, tinggal memilih sesuai kebutuhan. Namun selain alasan kemudahan mendapatkan pisang, ada alasan lain yang membuat pisang menjadi sangat penting dalam membuat banten. Pohon pisang tidak akan mati sebelum berbuah, bahkan ketika pohonnya ditebang sekalipun. Sepanjang masih ada akar pohon yang menancap, maka pohon pisang akan tumbuh lagi, menyelesaikan kewajibannya menghasilkan buah. Ini yang membuat buah pisang memiliki nilai yang tinggi untuk digunakan sebagai persembahan. Buah pisang adalah buah perjuangan dari pohon pisang. Tidak peduli cuaca buruk, terjangan hewan, campur tangan manusia, pohon pisang bertahan dan berjuang untuk menyelesaikan kewajibannya menghasilkan pisang dan memberikan kehidupan bagi makhluk hidup di sekitarnya. Pohon pisang mengajarkan bahwa menunaikan kewajiban adalah hal utama dalam hidup. Selesaikan kewajibanmu dan saat itulah kau memberikan makna pada hidupmu (http://blog.ayusmartbiz.com/2019/09/ filosofi-pisang.html).

Sukrawati, dkk (2018:110 - 111) menambahkan, bahwa, buah-buahan atau biji-bijian yang merupakan sarana dalam upacara Yadnya. Jenis buah-buahan atau biji-bijian banyak digunakan oleh umat Hindu sebagai persembahan dan sebagai wujud rasa terima kasih kehadapan Hyang Widhi, Yang Maha Pengasih dan Maha Pemberi. Diantara jenis buah-buahan yang paling sering digunakan sebagai sarana upacara Yadnya, seperti buah kelapa, buah pisang dan buah pinang.

Selain itu menurut Jro Mangku Ketut Wata (47 tahun) tokoh agama setempat dalam wawancaranya mengatakan :

"bahwa secara filosofi, bukan hanya berkaitan dengan penggunaan pisang sebagai salah satu sarananya, tetapi sesungguhnya tradisi Perang Pisang ini juga merupakan wujud pelaksanaan yadnya. Melalui tradisi Perang Pisang ini masyarakat Desa Tenganan Dauh Tukad bermaksud melaksanakan kewajiban mayadnya dengan mempersembahkan segala hasil bumi kehadapan Ida Sanghyang Widhi Wasa, yang terus menerus memberikan berkah anugrah berupa kesejahteraan dan kemakmuran bagi masyarakat kami disini" (Wawancara tanggal 12 Agustus 2019).

Berdasarkan hal tersebut di atas, maka digunakannya pisang dalam pelaksanaan perang pisang karena dilihat dari makna buah-buahan dalam upakara yadnya, seperti pisang adalah sebagai sarana persembahan dan wujud rasa terima kasih masyarakat kepada Ida Sang Hyang Widhi. Hal tersebut sesuai dengan makna perang pisang secara niskala yaitu untuk menyampaikan rasa syukur atau terima kasih masyarakat Desa Tenganan Dauh Tukad kepada Ida Sang Hyang Widhi atas segala hasil panen yang telah diperoleh. Selain itu, untuk mengajarkan masyarakat, khususnya para calon pemimpin di Desa Tenganan Dauh Tukad agar belajar dari filosofi pisang tersebut. Dalam hidup hendaknya harus selalu berjuang, tidak bermalas-malasan. Sebagai seorang pemimpin harus bisa 
menghasilkan sesuatu untuk orang lain (masyarakat), tidak boleh egois (bisa mengutamakan kepentingan umum daripada kepentingan pribadi), harus bisa menyelesaikan kewajiban terlebih dahulu sebelum kemudian menuntut hak.

\section{Landasan Sosiologi}

Secara sosiologis, tradisi Perang Pisang (mesabatan biu) merupakan tradisi bagi teruna adat di Desa Tenganan Dauh Tukad dalam memilih calon pemimpin, yaitu untuk memilih ketua dan wakil ketua teruna adat (pemuda). Keterlibatan teruna adat sebagai pelaku maupun hanya membantu dalam pelaksanaan tradisi perang pisang sangat menentukan keberhasilan pelaksanaan tradisi tersebut.

Menurut I Wayan Tisna, mantan Kelian seke teruna setempat, peserta Perang Pisang biasanya adalah para teruna adat yang sudah berusia sekitar 13 tahun ke atas. Dalam pelaksanaan perang pisang biasanya dipilih dua orang teruna adat yang bertugas sebagai saya dan penampih yang sudah ditentukan pada saat sasih Kenem, yang kemudian bertugas sebagai orang yang bertanggung jawab atas penyediaan sarana setiap upacara untuk keperluan selama 12 sasih ke depan dan berakhir pada sasih Kenem juga, serta secara otomatis sebagai bakal calon pengganti pemimpin sebelumnya. Makna perang pisang ini tentu melibatkan teruna adat dengan tujuan mencari pemimpin yang kuat secara fisik mapun mental. Dalam hal sebagai teruna adat ini yang dilibatkan sebagai penangung jawab dalam meminpin sebuah organisasi adalah sebagai regenerasi.

Keterlibatan seke teruna, jika dikaitkan dengan konsep ajaran Catur Asrama merupakan bagian dari proses pembelajaran dengan cara menempa diri baik secara fisik (fisikal) maupun nonfisik (mental, intelektual dan spiritual), dimana mereka akan dipersiapkan sebagai calon-calon pemimpin. Menurut konsepnya ajaran Catur Asrama berasal dari bahasa Sansekerta yaitu dari kata Catur dan Asrama. Catur yang berarti empat dan kata Asrama berarti tempat atau lapangan "Kerohanian". Kata "Asrama" sering juga dikaitkan dengan jenjang kehidupan. Jenjang kehidupan itu berdasarkan atas tatanan rohani, waktu, umur, dan sifat prilaku manusia.

Susunan tatanan itu mendukung atas perkembangan rohani seseorang. Perkembangan rohani berproses mulai dari bayi, muda, dewasa, tua, dan mekar. Kemudian berkembang menjadi rohani yang mantap mengalami ketenangan dan berkeseimbangan. Jadi Catur Asrama berarti empat jenjang kehidupan yang berlandaskan petunjuk kerohanian Hindu.

Adanya empat jenjang kehidupan dalam ajaran agama Hindu dengan jelas bahwa hidup itu di program menjadi empat fase dalam kurun waktu tertentu. Tegasnya dalam satu lintasan hidup diharapkan manusia mempunyai tatanan hidup melalui empat tahap program itu, dengan menunjukkan hasil yang sempurna. Dalam fase pertama, kedua, ketiga dan ke empat rumusan tatanan hidup dipolakan. Sehingga dapat digariskan bahwa pada umumnya orang yang berada dalam fase pertama dan tidak boleh atau kurang tepat menuruti tatanan hidup dalam fase yang kedua, ketiga ataupun ke empat. Demikian seterusnya diantara satu fase hidup dengan kehidupan berikutnya. Bilamana hal itu terjadi dan diikuti secara tekun maka kerahayuan hidup akan tidak sulit tercapai.

\section{2}

\section{VIDYA WERTTA}

Vol. 3 Nomor 1, April 2020 
Bilamana dilanggar tentu yang bersangkutan akan mendapatkan pengalaman sebaliknya.

Jadi untuk memudahkan menuju tujuan hidup maka agama Hindu mengajarkan dan mencanangkan empat jenjang tatanan kehidupan ini. Masingmasing jenjang itu, memiliki warna tersendiri dan semua jenjang itu mesti dilewati hingga akhir hayat dikandung badan. Setelah itu diharapkan Atma menjadi bersatu dengan sumbernya yaitu Parama Atma.

Adapun bagian-bagian ajaran Catur Asrama ini terdapat di dalam kitab Agastya Parwa yang menyuratkan :

"Catur Asrama ngaranya Brahmacari, Grhastha, Wanaprastha, Bhiksuka, Nahan tang Catur Asrama ngaranya".

Artinya :

Yang bernama Catur Asrama ialah Brahmacari, Grhastha, Wanaprastha, dan Bhiksuka.

Berdasarkan uraian dari Agastya Parwa itu menjadi sangat jelaslah pembagian Catur Asrama itu. Catur asrama ialah empat fase pengasraman berdasarkan petunjuk kerohanian. Dari ke empat pengasramaan itu diharapkan mampu menjadi tatanan hidup umat manusia secara berjenjang. Masing-masing tatanan dalam tiap jenjang menunjukkan proses menuju ketenangan rohani. Sehingga diharapkan tatanan rohani pada jenjang Moksa sebagai akhir pengasramaan dapat dicapai atau dilaksanakan oleh setiap umat.

Masing-masing jenjang dari memiliki kurun waktu tertentu untuk melaksanakannya. Pelaksanaan jenjang perjenjang ini hendaknya dapat dipahami dan dipandang sebagai kewajiban moral dalam hidup dan dan kehidupan ini. Dengan demikian betapapun beratnya permasalahan yang dihadapi dari masingmasing fase kehidupan itu tidak akan pernah dikeluhkan oleh pelakunya. Idialnya memang seperti itu, tidak ada sesuatu "permasalahan" yang patut kita keluhkan. Keluh-kesah yang kita simpan dan menguasai sang pribadi kita tidak akan pernah membantu secara ikhlas untuk mendapatkan jalan keluar dari permasalahan yang ada. Bila kita hanya mampu mengeluh tentu akan menambah beban yang lebih berat lagi. Hindu sebagai agama telah menggariskan kepada umatnya untuk tidak hanya biasa dan kaya mengeluh. Renungkanlah sloka suci Bhagawadgita, III. 42, dan 43 berikut ini :

"Niyatam kuru karma tvam, karma jyayo hy akarmanah, sarirayatra pi cha ten a prasidheyed akarmanah

Artinya :

Lakukan pekerjaan yang diberikan padamu karena melakukan perbuatan itu lebih baik sifatnya daripada tidak melakukan apa-apa, sebagai juga untuk memelihara badanmu tidak akan mungkin jika engkau tidak bekerja (Pudja, 1981: 64)

\section{3}

\section{VIDYA WERTTA}

Vol. 3 Nomor 1, April 2020 
"Yajnarthat karmamo nyatra, loko yam karma bandhanah, tadartham karma kaunteya, muktasangah samachara"

Artinya :

Kecuali pekerjaan yang dilakukan sebagai dan untuk yadnya dunia ini juga terikat oleh Hukum Karma. Oleh karenanya, O Arjuna, lakukanlah pekerjaanmu sebagai Yadnya, bebaskan dari semua ikatan (Pudja, 1981: $65)$.

Demikianlah Sri Bhagawan Kresna menjelaskan agar kita melakukan pekerjaan yang telah diwajibkan dengan benar dan tanpa terikat akan hasilnya. Tujuannya tiada lain adalah agar semua karma atau perbuatan yang kita lakukan diubah menjadi yoga, sehingga kegiatan itu dapat membawa kita menuju persatuan dengan Tuhan Yang Maha Esa. Bila seseorang melakukan perbuatan dengan kesadaran badan, yaitu bila mereka menyamakan dirinya sebagai manusia yang berbuat, maka perbuatannya itu tidak akan menjadi Karma Yoga. Setiap perbuatan yang dilakukan dengan perasaan mementingkan dirinya sendiri, dengan rasa keterikatan, yaitu merasa perbuatannya, maka semua perbuatan semacam itu akan mengakibatkan kesedihan. Sehubungan dengan itu, kitab Bhagawadgita, III, 50 menyatakan :

"Na buddhi bhedam janayed, ajananam karmasanginam, joshayet sarva karmani, vidvam yuktah samacharan"

Artinya :

Orang yang pandai seharusnya jangan menggoncangkan pikiran orang yang bodoh yang terikat pada pekerjaanya. Orang yang bijaksana melakukan semua pekerjaan dalam jiwa yoga, harus menyebabkan orang lain juga bekerja (Pudja, 1981: 70).

Dikaitkan dengan penelitian ini, keberadaan tradisi Perang Pisang yang berhubungan dengan pemilihan calon pemimpin, jelas sekali memiliki relevansi dengan para anggota seke teruna yang masih berada di dalam jenjang Brahmacari Asrama yang masih harus banyak menempa diri, baik secara fisik (fisikal) maupun nonfisik (mental, intelektual dan juga spiritual). Bagi mereka yang akan tampil sebagai pemimpin, terutama dalam lingkup seke teruna, wajib hukumnya untuk tidak hanya kuat fisiknya, tetapi juga mentalnya, berakhlak moralnya dan berbobot intelektualnya.

Hal ini sejalan dengan apa yang disampaikan mantan Kelian Seke Teruna bernama I Wayan Tisna (45 tahun) yang mengatakan :

"bahwa sebagai pemimpin seke teruna yang nantianya akan menjadi penerus kepemimpinan di desa adat, merupakan suatu keharusan terjadinya regenerasi. Sehingga melalui tradisi Perang Pisang ini, paling tidak mereka sudah dipersiapkan segala sesuautnya untuk siap tampil 
sebagai pemimpin kini dan masa datang" (wawancara tanggal 15 Agustus 2019).

Berdasarkan paparan dan hasil wawancara di atas dapat disimpulkan bahwa memang untuk menjadi seorang pemimpin itu di saat masih muda, sedang semangat belajar (brahmacari) perlu ditempa, tidak hanya fisikalnya saja tetapi juga mental, moral, intelektual dan bahkan spiritualnya. Sehingga beban tugas yang nantinya diamanatkan kepadanya bisa dijalankan dengan penuh rasa tanggungjawab, disiplin dan tentunya mampu membawa anggota yang dipimpin, terutama lagi masyarakat Desa Tenganan Dauh Tukad dapat mencapai apa yang dicita-citakan, khususnya mencapai kesejahteraan, kerukunan, kedamaian, dan kesuksesan.

\subsection{Prosesi dan Nilai-nilai Etika Hindu pada Tradisi Perang Pisang di Desa \\ Tenganan Dauh Tukad, Kabupaten Karangasem}

\section{Prosesi/Pelaksanaan Tradisi Perang Pisang}

\section{1) Persiapan}

Beberapa acara yang berkaitan dengan persiapan sebelum dilaksanakan tradisi Perang Pisang ini adalah :

\section{(a) Ngalang/Ngerampag I}

Dilaksanakan, lima hari sebelum Perang Pisang, dimana para seke teruna secara bersama-sama mencari bahan atau sarana perlengkapan berupa buahbuahan (kelapa, pisang, mangga, sawo, tabu, umbi-umbian, dll). Bermacam buahbuahan tersebut kemudian dikumpulkan di Bale Agung sebagai perbekalan (konsumsi), seperti tampak pada gambar 5.1 di bawah ini.

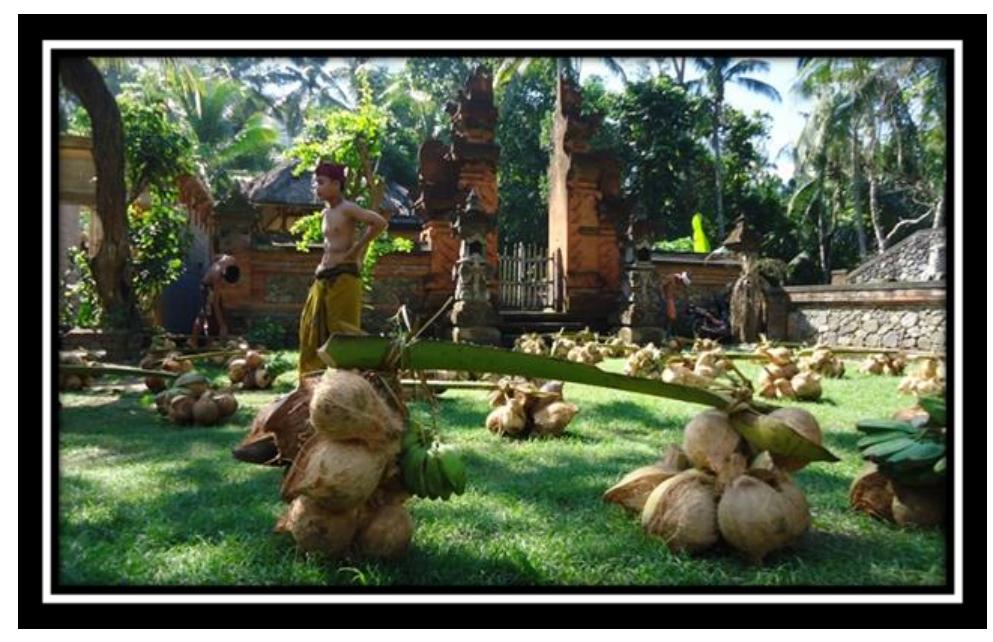

Hasil dari Ngalang/Ngerampag

\section{5}

\section{VIDYA WERTTA}

Vol. 3 Nomor 1, April 2020 
(Dokomentasi: I Wayan Dauh, 2019)

\section{(b) Ngantung Kambing}

Dilaksanakan empat hari sebelum Perang Pisang, yaitu membuat jajan yang menggambarkan beberapa jenis hewan/binatang termasuk manusia dan dikerjakan oleh kaum wanita (ibu-ibu). Jajan-jajan tersebut kemudian dirangkai lalu digantung di setiap palinggih/sanggah, baik milik keluarga maupun desa, seperti tampak pada gambar 5.2 berikut.

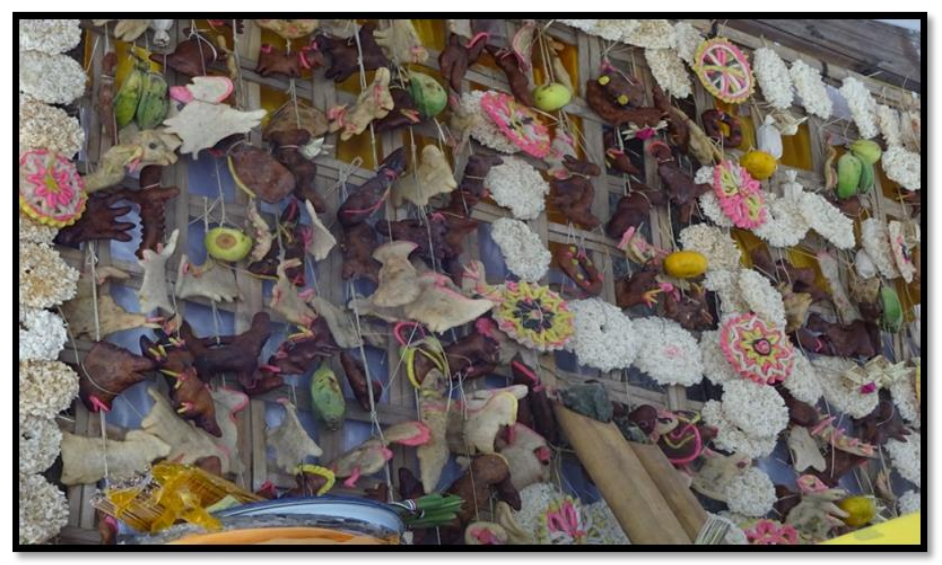

Ngantung Kambing berupa Jajan

(Dokomentasi: I Wayan Dauh, 2019)

\section{(c) Nyiramang Selonding}

Dilaksanakan dua hari sebelum Perang Pisang, yaitu memandikan instrument gambelan selonding yang akan mengiringi pelaksanaan tradisi Perang Pisang dan dilaksanakan oleh seke selonding itu sendiri, dibantu seke teruna.

\section{(d) Ngalang/Ngerampag II}

Sehari sebelum hari pelaksanaan tradisi Perang Pisang, para seke teruna melakukan acara mencari bahan atau sarana perlengkapan berupa buah-buahan tetapi tidak sebanyak jenis pada saat Ngalang/Ngerampag I, terutama yang dipentingkan saja yaitu buah kelapa, dan pisang). Jenis buah-buahan tersebut kemudian dikumpulkan di Bale Pesandekan di depan Pura Dalem Majapahit. Buah-buahan ini tidak digunakan sebagai perbekalan (konsumsi) melainkan sebagai alat/sarana dalam Perang Pisang.

Perihal jumlah kelapa yang dipikul, melalui wawancara dengan Kelian Dinas Tenganan Dauh Tukad I Nyoman Budiana (42 tahun) di dapat informasi bahwa: 
"Jumlah kelapa yang harus dipikul adalah sebanyak 20 buah, yaitu 10 buah dipikul di depan dan 10 buah dipikul di belakang. Jumlah tersebut sudah mengalami pergeseran yang sebelumnya adalah masing-masing peserta harus memikul sebanyak 40 buah kelapa. Pergeseran tersebut terjadi karena melihat kemampuan fisik teruna adat yang sekarang tergolong kecil dan agar tidak terlalu membebani bagi peserta ketika perang nanti. Sebab pada saat pelaksanaan perang, peserta harus bisa berkonsentrasi memikul sambil melakukan lemparan dengan tepat ke arah lawan. Kelapa yang dibawa (dipikul) adalah semua jenis kelapa dari hasil ngerampag, baik itu yang masih muda maupun yang tergolong sudah tua. Tidak adanya suatu keharusan menggunakan jenis kelapa tertentu dalam perang pisang ini. Selain itu, pisang yang digunakan juga dipetik langsung dari kebun milik desa maupun milik masyarakat. Pisang yang dipilih untuk digunakan dalam perang ini adalah pisang saba (Wawancara tanggal 16 Agustus 2019).

\section{(e) Penampahan}

Setelah acara Ngalang/Ngerampag II, dilanjutkan dengan acara "Penampahan" (meolah-olahan) yang dilaksanakan oleh para pengayah, dan akan digunakan untuk kepentingan sesaji (aci-yadnya) serta konsumsi masyarakat desa pada puncak acara tradisi Perang Pisang, seperti tampak pada gambar 5.3 berikut ini.

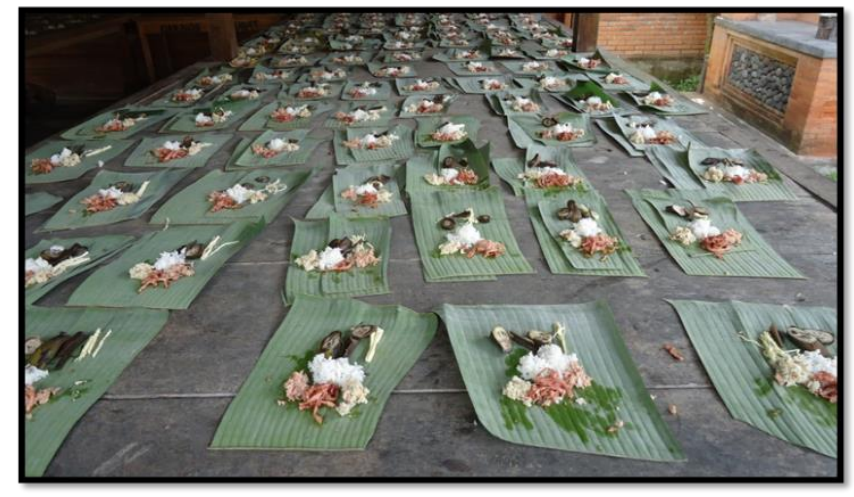

Sajian penampahan

(Dokomentasi: I Wayan Dauh, 2019)

\section{2) Pelaksanaan Tradisi Perang Pisang}

Rangkaian acara pelaksanaan tradisi Perang Pisang ini dibagi menjadi beberapa tahapan, yaitu :

(a) Matur Piuning

\section{7}

\section{VIDYA WERTTA}

Vol. 3 Nomor 1, April 2020 
Mulai pagi hari seluruh masyarakat desa melaksanakan kegiatan di Pura keluarga (sanggah) masing-masing yaitu matur piuning bahwa akan mengikuti acara tradisi Perang Pisang agar dianugrahi keselamatan.

\section{(b) Persembahyangan bersama}

Setelah selesai acara matur piuning di rumah masing-masing, seluruh masyarakat desa menuju ke Pura Dalem untuk melaksanakan persembahyangan bersama. Tujuannya, sebagai ungkapan rasa terimakasih kehadapan Ida Sanghyang Widhi atas keberlimpahan hasil bumi dan dapat melaksanakan aci tradisi Perang Pisang. Upacara persembahyangan bersama ini juga dimaksudkan untuk memohon kelancaran dan keselamatan dalam pelaksanaannya. Sekaligus diharapkan agar tidak terjadi insiden apapun, termasuk tidak menimbulkan rasa dendam setelah selesai tradisi Perang Pisang tersebut, justru hubungan antar masyarakat semakin erat atau akrab.

\section{(c) Tabuh Selonding}

Usai persembahyangan bersama, sebagai penciri akan dimulainya Perang Pisang, seke selonding menabuh gambelan selonding yang berirama gegilakan yang dapat mendorong rasa semangat, keperwiraan atau kegagahberanian para seke teruna yang akan terlibat langsung dalam Perang Pisang. Terutama yang duduk sebagai "Saye" (calon pemimpin/ketua) dan "Penampih (calon wakil ketua), yang jauh sebelumnya (sekitar 3 bulan lalu) memang sudah ditunjuk untuk maju sebagai sebagai "Saye" dan "Penampih", yang dilaksanakan di Bale Agung melalui Paruman Teruna Desa.

\section{(d) Puncak Acara Perang Pisang}

Dimulai dengan bergeraknya para seke teruna lengkap dengan memanggul/memikul (negen) kelapa sebanyak 20 butir (di depan 10, di belakang 10) yang sudah dikupas kulitnya, ditambah masing-masing 1 tandan buah pisang saba mentah, sebagai sarana melempar (masabatan) pihak "Saye" dan "Penampih", seperti tampak pada gambar 5.3 berikut.

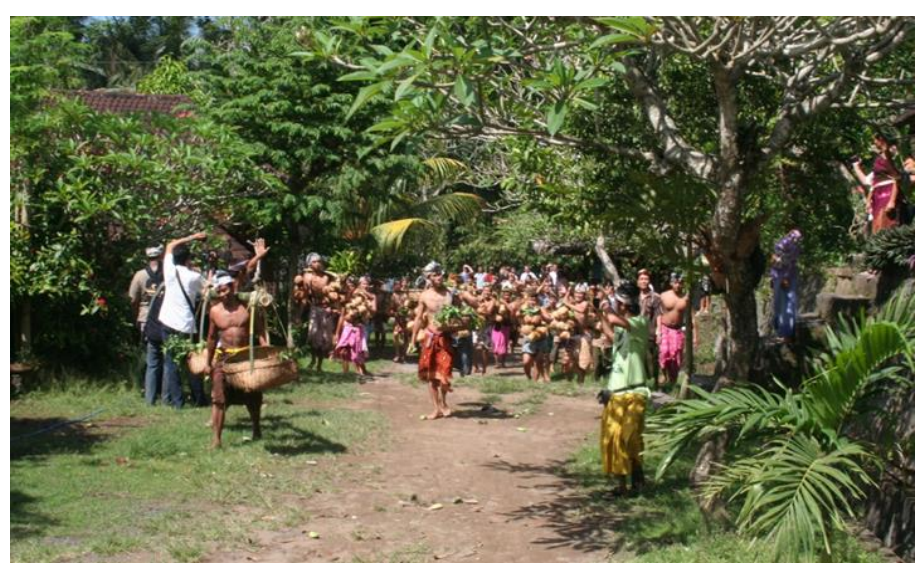

Acara Perang Pisang dimulai

\section{8}

\section{VIDYA WERTTA}

Vol. 3 Nomor 1, April 2020 
Upacara perang pisang atau mesabatan biu ini digelar di pelataran Pura Bale Agung, dalam rangka pemilihan ketua (Saye) dan wakil ketua (Penampih) seke teruna setempat. Setelah segala perlengkapan siap, maka dengan diiringi gambelan selonding terjadilah Perang Pisang, yaitu para anggota seke teruna masing-masing dengan bawaannya mengambil satu demi satu pisang pada tandannya untuk digunakan melempar "Saye" dan "Penampih" yang sama sekali tidak boleh melawan/membalas, kecuali hanya menghindar. Acara Perang Pisang ini diikuti oleh 16 pemuda desa yang dipilih oleh kelian adat untuk dilawankan dengan 2 orang (calon ketua dan wakil). Sebelum upacara ini dimulai para pemuda ini mencari pisang dan kelapa, dan pisangnya untuk digunakan sebagai senjata dalam perang. Acara Perang Pisang ini melibatkan 16 pemuda, dimana mereka sudah berkumpul di suatu tempat, di ujung desa sekitar 300 meter dari Pura Bale Agung, berganti pakaian sehari-hari dengan menggunakan kamben, udeng (penutup kepala) dan tanpa baju dan menunjukkan mereka sudah dewasa, dan ke-2 pemuda sudah berdiri di jalan berlawanan. Para tetua laki-laki duduk duduk di atas bale yang terletak di Jeroan Bale Agung, sedangkan para ibu menyiapkan makanan khusus untuk megibung (ritual makan bersama). Para bapak, pemuda-pemudi dan anak-anak, kelihatan berjejer di sepanjang jalan yang akan menyaksikan berlangsungnya perang.

Setelah ada aba-aba dari Kelian Adat Tenganan Daud Tukad, pertanda perang dimulai, para pemuda dengan langkah setengah berlari menuju pertengahan jalan antara pura dan ujung jalan, dan di sini perang di mulai, dua pemuda yang menjadi sasaran perang dan diperbolehkan untuk melawan tentu akan kewalahan karena perang yang tak seimbang, namun demikian kaki mereka terus melangkah menuju pura, karena mereka tidak boleh berhenti, apalagi sampai tergopoh-gopoh dan jatuh, kalau itu terjadi mereka akan dianggap gagal dan tidak pantas menjadi pemimpin.

Para anggota seke teruna masing-masing dengan bawaannya mengambil satu demi satu pisang pada tandannya untuk digunakan melempar "Saye" dan "Penampih" yang sama sekali tidak boleh melawan/membalas, kecuali hanya menghindar. Meskipun sudah berusaha menghindar dalam praktiknya tidak jarang pihak "Saye" atau "Penampih" menjadi bulan-bulanan lemparan anggota seke teruna, hingga tubuh atau muka lebam-lebam, bahkan pernah juga sampai roboh, dan hal itu dianggap sebagai sebuah kekalahan. Jika hal itu terjadi maka, "Saye" atau "Penampih" tersebut akan segera dicarikan pengganti pada saat itu juga, sesuai daftar urut calon yang sebelumnya memang sudah disiapkan/ditetapkan.

Upacara akan berakhir setelah ke-2 calon ketua dan wakil pemuda ini sampai di pintu gerbang Pura Bale Agung, sehingga setelah melewati pintu gerbang mereka dianggap lulus dan dengan wajah lebam-lebam. Tujuan adanya pemilihan dengan perang pisang ini untuk mencari pemimpin yang kredibel, kuat mental dan fisik menghadapi persoalan yang semakin komplek. Tenganan memang unik selain tradisi perang pisang, juga memiliki Tradisi Perang Pandan atau Mekare-kare (https://panbelog.wordpress.com).

\section{9}

\section{VIDYA WERTTA}

Vol. 3 Nomor 1, April 2020 


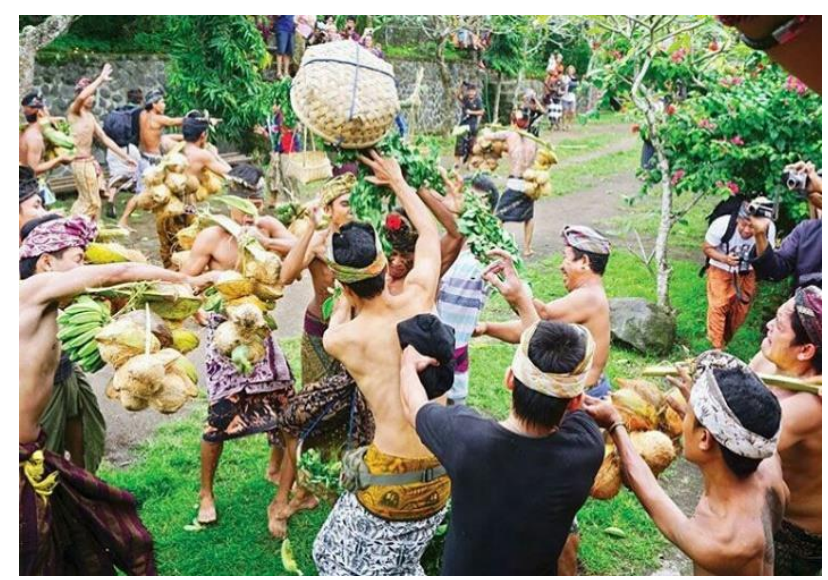

Pelaksanaan Perang Pisang

(Sumber : https://panbelog.wordpress.com)

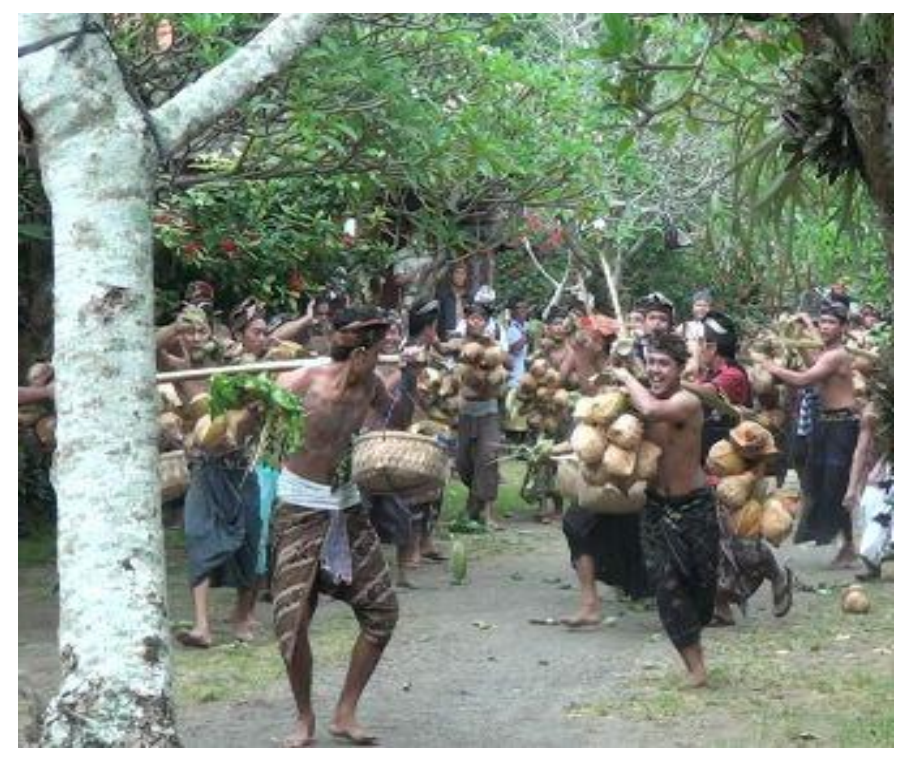

\section{Gambar 5.5 (b) Saling serang dalam Perang pisang}

\section{PENUTUP}

Tradisi Perang Pisang dilaksanakan masyarakat Desa Tenganan Dauh Tukad didasari oleh beberapa landasan, yaitu : 1) landasan histori, berkaitan dengan usaha Jro mangku Dukuh untuk melestarikan tradisi Perang Pisang; 2) landasan teologi, yaitu sebagai ungkapan rasa angayubagia (terimakasih dan syukur) kehadapan Ida Sanghyang Widhi/Tuhan Yang Maha Esa atas anugrah kemakmuran yang dinikmati masyarakat; 3) landasan filosofi, berhubungan dengan kepercayaan bahwa tradisi Perang Pisang itu sesungguhnya adalah sebagai bentuk persembahan yadnya juga; dan 4) landasan sosiologi berhubungan 
erat dengan struktur kepemimpinan sosial masyarakat desa Tenganan Dauh Tukad terutama dalam hal memilih calon pemimpin (ayah dan penampih) dari seke terunanya agar memperoleh pemimpin yang sesuai dengan nilai-nilai etika Hindu. Prosesi tradisi Perang Pisang ini dimulai dari tahap persiapan, pelaksanaan dan penutup yang kesemua itu dijalankan dengan penuh kepatuhan oleh masyarakat setempat. Sedangkan nilai-nilai etika yang terdapat pada tradisi Perang Pisang.

\section{DAFTAR PUSTAKA}

Arik Restia Dewi, Ni Made. 2007. Upacara Perang Ketupat Di Pura Desa Adat Kapal Mengwi, Badung (Ditinjau Dari Nilai-Nilai Pendidikan Agama Hindu). Program Sarjana Ilmu Filsafat Kekhususan Pendidikan Agama Hindu, Universitas Hindu Indonesia.

Atmaja, Nada, dkk. 2010. Etika Hindu. Surabaya : Paramita.

Atmaja, Nengah Bawa. 2005. Metode Penelitian Kualitatif. Institut Keguruan dan Ilmu Pendidikan Negeri Singaraja.

Dauh, Wayan, 2018. Jurnal Widyanatya Pendidikan Agama Dan Seni, Universitas Hindu Denpasar. Terbitan volume 7

Donder, I Ketut dan I Ketut Wisarja. 2010. Filsafat Ilmu. Surabaya : Paramita.

Danim, Sudarwan. 2002. Menjadi Peneliti Kualitatif. Bandung : CV. Pustaka Setia.

Kajeng, I Nyoman. Dkk. 1997. Sarasamuccaya. Surabaya : Paramita.

Kaelan. 2010. Metode Penelitian Agama Kualitatif Interdisipliner. Yogyakarta : Paradigma.

Kartono, Kartini. 1994. Pemimpin dan Kepemimpinan. Jakarta: Rajawali

Koentjaraningrat. 1984. Kebudayaan, Mentalitas dan Pembangunan. Jakarta : PT. Gramedia.

\section{1}

\section{VIDYA WERTTA}

Vol. 3 Nomor 1, April 2020 
Mardalis. 1995. Metode Penelitian suatu Pendekatan Proposal. Jakarta: Bumi Aksara

Poedjawijatna. 1986. Etika Filsafat Tingkah Laku. Jakarta : PT Bina Aksara

Rachman, Abdul. 2009. Kerangka Pokok-pokok Mengenai Management Umum. Bandung: Rosda

Subagiasta, I Ketut. 2006. Teologi, Filsafat, Etika Dan Ritual. Surabaya: Paramita.

Sumiarti, Ni Made. 2007. Fungsi Api dalam Upacara Yadnya Ditinjau dari Pendidikan Agama Hindu, Skripsi. Denpasar: Universitas Hindu Indonesia.

Murgiyanto, Sal. 2004. Tradisi dan Inovasi. Jakarta : Wedatama Widya Sastra

Saba, I Ketut. 2001. "Arja Muani dalam Masyarakat Bali; Sebuah Perspektif Kajian Budaya". Tesis Program Pascasarjana Universitas Udayana.

Satori, Djam'an dan Aan Komariah. 2011. Metodologi Penelitian kualitatif. Bandung : Alfabeta

Sudadi dan Watra. 2007. Dasar-Dasar Filsafat (Pengantar Filsafat). Surabaya : Paramita.

Sudijono, Anas. 2006. Pengantar Evaluasi Pendidikan. Jakarta : Raja Grafindo Persada.

Sugiyono. 2008. Memahami Penelitian Kualitatif. Bandung : Alfabeta.

Suparyoga dan Tambroni. 2001. Metodelogi Penelitian Sosial Agama. Bandung : PT. Remaja Rosdakarya.

Tim Penyusun. 2012. Kepemimpinan Hindu. Institut Hindu Dharma Negeri Denpasar.

Tim Penyusun. 2012. Metodologi Penelitian. Direktorat Jenderal Bimbingan Masyarakat Hindu Kementerian Agama RI.

Wiratmadja, I Gusti Ketut Adia, dan I Gusti Ngurah Nala. 1977. Murdha Agama Hindu (Indonesia). Yogyakarta : Tanpa Penerbit.

\section{Rujukn Internet :}


http://sumantre.blogspot.com/2010/10/hukum-hindu-sumber-sumber-hukumhindu.html).

http://blog.ayusmartbiz.com/2019/09/ filosofi-pisang.html.

https://panbelog.wordpress.com.

https://kbbi.web.id/pemimpin

\section{Daftar Informan}

1. $\mathrm{N}$ a $\mathrm{m}$ a I Nyoman Puri

Tempat, Tgl lahir $\quad$ : Karangasem, 10 Oktober 1970

Pekerjaan : Wiraswasta

Jabatan $\quad:$ Bendesa adat Tenganan Dauh Tukad

Alamat : Desa Adat Tenganan Dauh Tukad

2. $\mathrm{N}$ a $\mathrm{m}$ a : I Wayan Togiya

Tempat, Tgl lahir $\quad$ : Karangasem, 25 Juni 1974

Pekerjaan : Wiraswasta

Jabatan : Sekeretaris Bendesa adat Tenganan Dauh Tukad

Alamat : Desa Adat Tenganan Dauh Tukad

3. $\mathrm{N}$ a $\mathrm{m}$ a I Nyoman Budiana

Tempat, Tgl lahir : Karangasem, 25 Mei 1977

Pekerjaan : Wiraswasta

Jabatan : Kelian Dinas Tenganan Dauh Tukad

Alamat : Desa Adat Tenganan Dauh Tukad

4. $\mathrm{N}$ a $\mathrm{m}$ a : Jro mangku Ketut Wata

Tempat, Tgl lahir : Karangasem, 10 September 1972

Pekerjaan : Pegawai PDAM

Jabatan : Pamangku Desa

Alamat : Desa Adat Tenganan Dauh Tukad

5. $\mathrm{N}$ a $\mathrm{m}$ a : I Wayan Tisna 
Tempat, Tgl lahir

Pekerjaan

Jabatan

Tukad

Alamat
: Karangasem, 25 Juni 1986

: Pedagang

: Mantan Kelian Seke Truna Tenganan Dauh

: Desa Adat Tenganan Dauh Tukad 